\title{
ArcheoSciences
}

Revue d'archéométrie

\section{Rectangular Beads from the Final Gravettian Level of the Abri Pataud: Raw Material Identification and its Archaeological Implications}

Les perles rectangulaires du Gravettien Final de l'abri Pataud: identification de la matière première et ses implications archéologiques

C. Vercoutère, Katharina Müller, L. Chiotti, R. Nespoulet, A. Staude, H. Riesemeier and I. Reiche

\section{OpenEdition}

\section{Journals}

\section{Electronic version}

URL: https://journals.openedition.org/archeosciences/3297

DOI: 10.4000/archeosciences.3297

ISBN: 978-2-7535-1849-0

ISSN: 2104-3728

\section{Publisher}

Presses universitaires de Rennes

\section{Printed version}

Date of publication: 30 April 2011

Number of pages: 259-271

ISBN: 978-2-7535-1847-6

ISSN: 1960-1360

Electronic reference

C. Vercoutère, Katharina Müller, L. Chiotti, R. Nespoulet, A. Staude, H. Riesemeier and I. Reiche,

"Rectangular Beads from the Final Gravettian Level of the Abri Pataud: Raw Material Identification and its Archaeological Implications", ArcheoSciences [Online], 35 | 2011, Online since 30 May 2013, connection on 01 March 2022. URL: http://journals.openedition.org/archeosciences/3297 ; DOI: https://doi.org/10.4000/archeosciences.3297 


\title{
Rectangular Beads from the Final Gravettian Level of the Abri Pataud: Raw Material Identification and its Archaeological Implications
}

\author{
Les perles rectangulaires du Gravettien Final de l'abri Pataud: \\ identification de la matière première et ses implications archéologiques
}

\author{
C. Vercoutère*, K. Müller **, L. Chiotti ${ }^{* * *}$, R. Nespoulet* $^{*}$, A. Staude ${ }^{* * * *}$, \\ H. RiesEMEIER ${ }^{* * * *}$ and I. ReICHE ${ }^{* *}$
}

\begin{abstract}
The Final Gravettian level (level 2) of the abri Pataud (Dordogne, France) yielded a large assemblage of body ornaments that consists essentially of 85 quite standardized rectangular beads. Some uncertainty remained about the raw material in which these small beads were made: mammoth ivory, reindeer antler or bone? Non-invasive methods were employed in order to determine the raw material. First chemical analyses using microbeam Proton Induced X-ray Emission analysis (microPIXE) did not enable us to conclude definitively. Therefore, synchrotron and laboratory X-ray microtomography (microCT) were applied on eight beads and allowed us to identify ivory for all of them except for one, which shows slightly different morphological features.

Due to their association with the human remains of level 2, these rectangular beads could be considered, like other "extraordinary" objects, as mortuary deposits. In this level, bones and reindeer antler are very abundant whereas mammoth ivory is rare: only one tusk fragment, seven raw ivory fragments, nine other beads and pendants have been found.

These new studies confirm that most rectangular beads are made of mammoth ivory. For the first time, we are able to demonstrate the exceptional status of this type of beads not only because of their archaeological context, but also due to the choice of raw material for their manufacture.

Résumé : Le niveau 2 (Gravettien final) de l'abri Pataud (Dordogne, France) a livré un nombre important d'éléments de parure. L'essentiel (n : 85) correspond à des perles rectangulaires assez standardisées. Certaines incertitudes demeuraient sur leur matière première : ivoire de mammouth, bois de renne ou os? Des méthodes non-invasives ont alors été employées pour déterminer la nature précise de celles-ci. Les analyses élémentaires par spectrométrie d'émission X induite par particules (PIXE) n'ayant pas été concluantes, la microtomographie de rayons X en laboratoire et au synchrotron a été utilisée sur huit perles et a permis d'identifier le matériau comme étant de l'ivoire, excepté pour l'une d'entre elles qui présente quelques légères différences de structure. Du fait de leur association avec les restes humains du niveau 2, ces perles rectangulaires peuvent être considérées, à l'instar des autres objets " extra-ordinaire", comme des dépôts mortuaires. Dans ce niveau, l'os et le bois de renne sont des matériaux abondants, alors que l'ivoire de mammouth est rare: seuls un fragment de défense, sept fragments d'ivoire bruts et neuf autres perles et pendeloques ont été trouvés.

Ces nouvelles études confirment que la majeure partie des perles rectangulaires a été réalisée en ivoire de mammouth. Nous pouvons donc, pour la première fois, démontrer le statut exceptionnel de ce type de perles tant par leur contexte archéologique que par la nature de la matière première choisie.
\end{abstract}

Keywords: abri Pataud, Final Gravettian, mammoth ivory, microPIXE, microCT, rectangular beads.

Mots clés : abri Pataud, Gravettien Final, ivoire de mammouth, microPIXE, microCT, perles rectangulaires.

* Département de Préhistoire du Muséum national d’histoire naturelle, UMR 7194, Institut de Paléontologie Humaine - 1 rue René-Panhard, 75013 Paris.(cvercout@mnhn.fr)

** Laboratoire du Centre de Recherche et de Restauration des Musées de France, UMR 171 - Palais du Louvre, 14 quai F.-Mitterrand, 75001 Paris.

*** Département de Préhistoire du Muséum national d'histoire naturelle, UMR 7194, abri Pataud- 20 rue du Moyen-Âge, 24620 Les Eyzies-de-Tayac.

**** Federal institute for materials research and testing (BAM) - Unter den Eichen 87, 12205 Berlin, Germany. 


\section{INTRODUCTION}

Bone materials have been used for the manufacture of artifacts and art works since prehistoric periods. The determination of the nature and characteristics of the raw material used is one of the key questions for archaeological and anthropological interpretation, being inevitably linked to the way in which raw materials were exploited by Man in ancient times. Ivory, bone and antler exhibit specific morphological characteristics, which, in general, enable a visual identification of the respective material by macro- and microscopic observations. However, this is not always possible on artifacts that are fully worked, small and/or fragmentary or diagenetically altered. Moreover, some of them have undergone invasive modern treatments (e.g. varnish and glue).

This is the case of a specific type of rectangular beads from the Final Gravettian level (level 2) of the abri Pataud (Dordogne, France). In order to identify the raw material of these archaeological body ornaments two conditions were required: a) the use of non-invasive methods; b) these methods must be sensitive to specific differences between different kinds of osseous materials (especially bone, antler and ivory), even for ancient artifacts. Therefore, two methods, developed by four of us (Reiche et al., 2011; Müller \& Reiche, 2011), were chosen: chemical analyses using microbeam Proton Induced X-ray Emission analysis (micro PIXE) and synchrotron and laboratory X-ray microtomography (microCT).
This article presents the results and limits of the employed methods when they were applied to Pataud rectangular beads. These chemical and microstructural analyses allow us to open a new discussion about the archaeological implications of the raw material identification in term of animal exploitation and social systems of which body ornaments are essential components (White, 1995; Vanhaeren, 2002).

\section{Archaeological context}

The abri Pataud is located at Les Eyzies-de-Tayac (Dordogne, France; fig. 1). The main excavations of this site were those managed by H. L. Movius from 1958 to 1964 (Movius, 1977; Bricker, 1995). He divided the filling of the rock-shelter into 14 archaeological levels, which follow each other in stratigraphical continuity from the Early Aurignacian to the beginning of the Solutrean (fig. 2). Therefore, Pataud is a key site for the knowledge of the first half of the Upper Palaeolithic in southwestern France.

The archaeological material from level 2 was attributed to the Final Gravettian, around 22000 years BP. Since 2005, a new multidisciplinary research project has been conducted under the direction of R. Nespoulet and L. Chiotti. Essentially, this study aims at a better understanding of the status of the human remains discovered within this level 2. Therefore, this new program includes several approaches: new excavations adjoining those of Movius, study of the Movius collections, analysis of the Movius archives
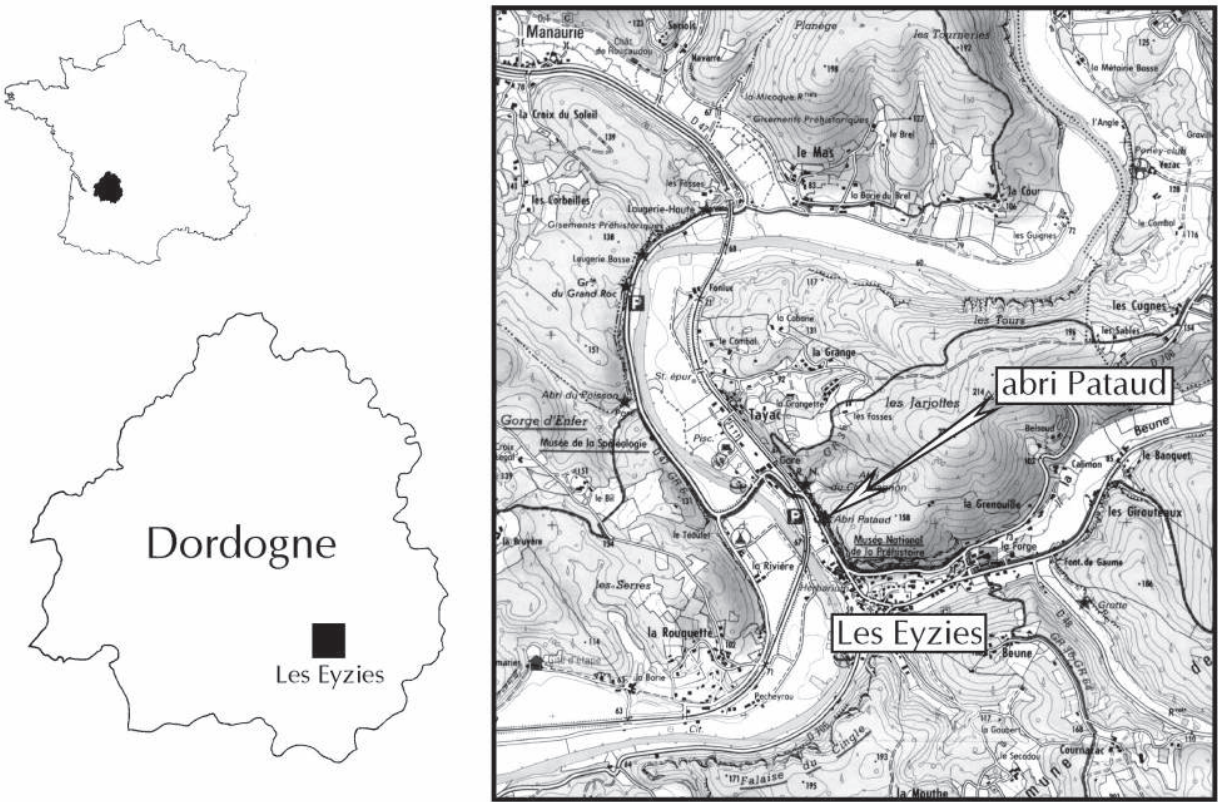

Figure 1: Geographical location of the abri Pataud (Les Eyzies-deTayac, Dordogne, France). Figure 1: Localisation géographique de l'abri Pataud (Les Eyzies-deTayac, Dordogne, France). 


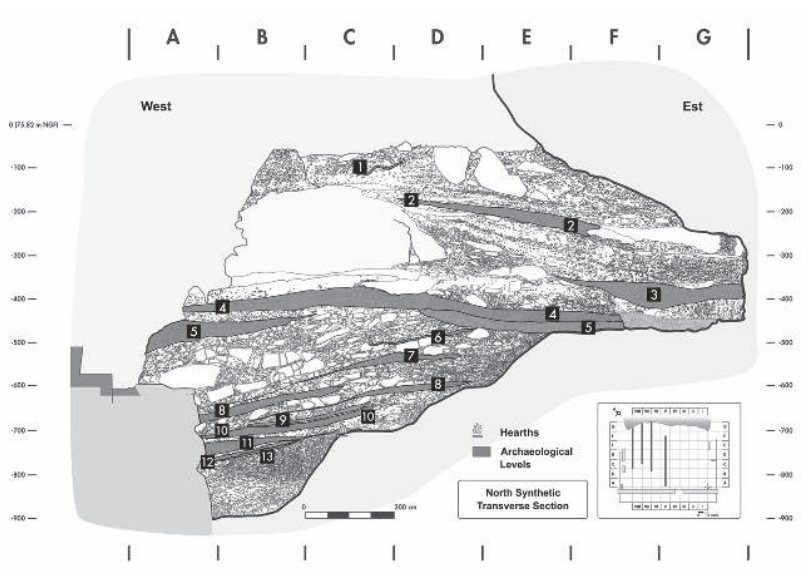

Figure 2: (See colour plate) Stratigraphical sequence of the abri Pataud (synthetic north section).

Figure 2: (Voir planche couleur) Séquence stratigraphique de l'abri Pataud (coupe synthétique nord).

(Nespoulet et al., 2008) and more precise material characterization of archaeological material such as pigments and osseous artifacts.

Level 2 corresponds to recurrent base camp type occupations. It yielded thousands of archaeological objects (faunal remains, lithic and bone industries, painted and engraved wall fragments from ancient parietal decoration, charcoals) among which more than four hundred human bones and teeth. The latter objects represent one of the most important series of human remains for the French Gravettian and the only known for the European Final Gravettian (22-20 000 years BP) today. Within the rock-shelter, human remains of level 2 were all located within the rear zone. A north concentration of human remains could be identified as a mortuary deposition (Nespoulet et al., 2008; Henry-Gambier et al., in prep.).

In this level, some artifacts were qualified as extra-ordinary because of their scarcity in comparison with the other types of remains in level 2, their space location (rear part of the shelter), their raw material and their high technical investment and apparently long use.

We were able to demonstrate that some of these extraordinary objects were associated with the north human remains concentration, and could thus be considered as mortuary deposits (Chiotti et al., 2009). The rectangular beads are part of these deposits.

\section{Archaeological data about THE RECTANGULAR BEADS From Pataud LeVel 2}

The Movius collection and the new excavations (from 2005 to 2010) altogether yielded thousands of archaeological objects. Apart from human remains, bone and lithic industries, faunal remains and many fragments of painted wall from an ancient parietal decoration, there are a great number of body adornments: 109 pieces (Table I). Most of these body ornaments consists of rectangular beads ( 85 pieces; fig. 3).

Sixty-three were discovered in 1963 , very concentrated in a $10 \mathrm{~cm}$ diameter circle, in direct association with a concentration of human remains. All the others, more scattered, were also found in the same sector. In the frame of a new research program, we were able to demonstrate that these rectangular beads were associated with the human remains of level 2 and that they could be considered as mortuary deposit (Chiotti et al., 2009).

A closer look on these rectangular beads indicates the problem of their raw material identification. The beads are really small, polished and, for the most part, varnished. These beads are relatively standardized and elaborated: they have a rectangular shape with a central perforation made by rotary movements with a flint tool. Considering only the intact beads ( 71 of 85 ), the main pattern consists in a bead with one flat side and the other curved $(94 \%$ of the intact beads). In this case, a transverse incision that crosses the perforation on the flat side is noticed (fig. 3), except for one piece that does not show any incision on its flat side. It

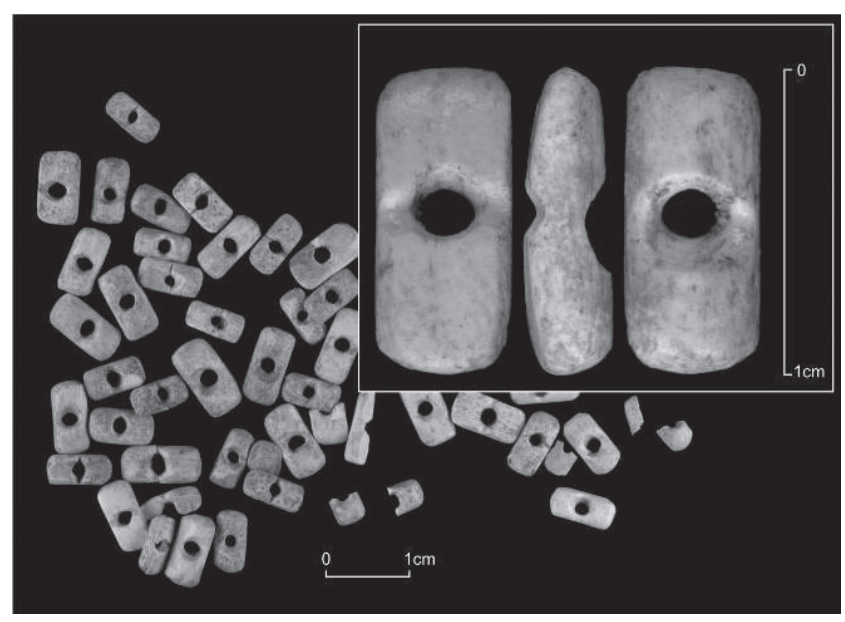

Figure 3: Rectangular beads from the Final Gravettian of the abri Pataud.

Figure 3: Perles rectangulaires du Gravettien Final de l'abri Pataud. 


\begin{tabular}{|l|c|c|}
\hline Category & $\mathrm{Nb}$ & $\%$ \\
\hline Worked tooth & 8 & 7,3 \\
\hline Pierced shell & 3 & 2,8 \\
\hline Perforated pebble & 1 & 0,9 \\
\hline Rectangualr bead & 85 & 78,0 \\
\hline Bead & 2 & 1,8 \\
\hline Pendant & 9 & 8,3 \\
\hline Worked ivory fragment & 1 & 0,9 \\
\hline TOTAL & 109 & \\
\hline
\end{tabular}

Table 1: Body adornments from the Final Gravettian of the abri Pataud (considering Movius' collections and new excavations). Tableau 1 : Eléments de parure du Gravettien Final de l'abri Pataud (prenant en compte les pièces des collections Movius et celles des nouvelles fouilles).

is, however, supposed that this side is more likely a broken surface than the side manufactured by a prehistoric craftsman. Only two beads have two curved sides, as for instance the bead AU_AP_30, and two others have two flat sides (one of them is unfinished). Is this slight shape difference due to a difference in raw material or are these beads a part of another kind of body ornamentation? We do not have enough objects and clues about their arrangement within a personal adornment to answer now. Figure 4 shows the dimensions measured for the complete beads. Length is the most fluctuating measurement (fig. $4 \mathrm{a}$ ), but most beads fit between 7.0 and $9.0 \mathrm{~mm}$. Width and thickness (fig. 4 b\&c) are more constant. About half of the pieces $(55 \%)$ are 4.0 mm wide and there are two main classes of thickness: 2.0 and $2.5 \mathrm{~mm}$ (32\% and $50 \%$ respectively). Finally, the most stable dimension is the diameter of the perforation (fig. $4 \mathrm{~d} ; 80 \%$ measured $2.0 \mathrm{~mm}$ ), directly linked to the size and shape of the flint borer used. It is difficult to interpret the little fluctuations in bead size, but we could suggest a way of manufacturing not so standardized and we cannot also exclude the intrinsic constraints of the raw material. Moreover, some evidence shows that beads were worn (e.g. the deformation of the perforation and the partially or completely erased technical traces; the intensity of polishing is more difficult to evaluate because of the varnish that covers most of the beads) and used as body ornaments. Therefore, it is interesting to underline that these beads were not especially manufactured for a mortuary deposition. Hence, the first hypothesis would be that people were buried with their own body ornamentation and that these rectangular beads reflect a part of the body ornamentation of the living.

Since, at the abri Pataud, these type of rectangular beads were discovered only in association with mortuary deposits (Chiotti et al., 2009), an other hypothesis would be that prehistoric people could have made a choice of a particular type of ornaments made of a specific raw material; a choice that could be linked with the mortuary context and also with the social status of people who were buried. Unfortunately, even if some arguments of "social inequality" were demonstrated for the Magdalenian hunter-gatherer societies (e.g. Vanhaeren \& d'Errico, 2003, 2005), we are not able now to make such inferences for the Gravettian period (HenryGambier, 2008).
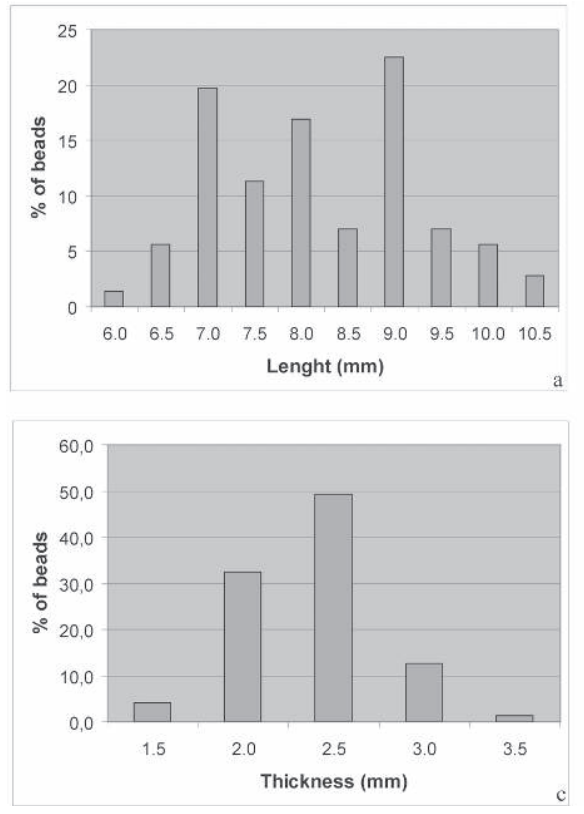
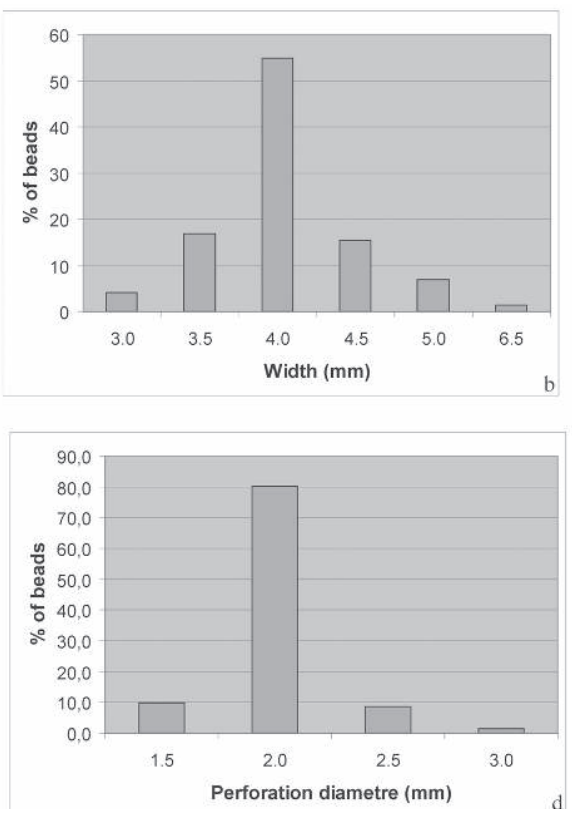

Figure 4: Dimensions of the rectangular beads from Pataud level 2 (note: only complete beads are considered here ( $\mathrm{n}$ : 71); $\mathrm{mm}=$ millimeter).

Figure 4: Dimensions des perles rectangulaires du niveau 2 de l'abri Pataud (note: seules les perles entières sont prises en compte ici (n: 71); $m m$ = millimètre). 
Since Movius' excavations the question about the raw material of the abri Pataud rectangular beads has been asked, as indicated on the excavation cards (e.g. "bone (or? ivory) bead of flattened rectangular shape with perforation at center"). A first short description of these beads was given by R. Clay (1968: 305), who mentioned: "they are made from the surface of reindeer bone which has been considerably thinned". However, until now, neither the study of the Movius collections (Vercoutère, 2007), nor that of the osseous material from the new excavations, have provided some artifacts or waste products that could allow us to reconstruct such a chaîne opératoire. Moreover, when examined with stereomicroscope, none of these rectangular beads show Haversian channels, which containing blood vessels and are characteristic of compact bone structure (Barone, 1986; Currey, 2002).

On the other hand, we noticed some cleavage planes on certain beads (e.g. AP26 on fig.5), which could induce the spalling of little fragments (e.g. AP 24 and 27 on fig. 5), or even the breakage of the artifacts (e.g. AP 21 on fig. 5). These cleavage planes seem to follow the typical structure of mammoth ivory, they appear upon the dessication of this material (Christensen, 2004; Poplin, 1995) and we also noticed them for other ivory artifacts and raw fragments from Pataud level 2.

These macroscopic visual observations led us first to strongly expect that Pataud beads were made of mammoth ivory. But, due to their small size and their polishing, we could not see more explicit structural characteristics, as for example the drawing of the Schreger pattern (Locke, 2008). Moreover, very similar rectangular beads, which seem to be characteristic of the Final Gravettian period, are present on three of the four sites known for this period in France: abri Pataud (n: 85), Les Peyrugues (Lot; n: 25; Allard et al., 1997) and Le Blot (Haute-Loire; n: 1; Chauvière \& Fontana, 2005). The beads from Les Peyrugues were published as made of reindeer antler (Allard et al., ibid.). Therefore, we could not totally exclude the use of reindeer antler and/or bone in order to manufacture Pataud beads.

Prior to address the question about the potential link between a specific raw material choice (ivory) and the mortuary context (with which Pataud beads were associated), we need to identify unambiguously the raw material of these Pataud rectangular beads.

Two non-destructive analytical approaches for the identification of bone materials, recently established at the C2RMF, were applied on a selection of rectangular beads from the Final Gravettian level of the abri Pataud. On one hand, micro Proton Induced X-ray Emission (microPIXE) can allow bone material identification and on the other hand microtomography (microCT) proved to be an effective tool.

Within the frame of a microPIXE study on a great number of modern, historical and archaeological ivory, bone and antler artifacts covering a wide time range (500-32 $000 \mathrm{BP}$ ) chemical markers for the identification of some bone materials were established (Müller \& Reiche, 2011).

Bone materials, comprising bone, antler and ivory, are hierarchical composites that are all basically composed of carbonated hydroxyapatite and collagen type I and show therefore very similar chemical composition with only slight variations in the minor and trace element contents (e.g. Christensen, 1999). The microPIXE study showed that modern ivory differs from modern bone and antler by the magnesium to calcium ratio, which is clearly enhanced in ivory ( 0.08 in elephant ivory versus 0.02 in bone or antler (Müller \& Reiche, 2011). Furthermore, the study revealed that the magnesium to calcium ratios of archaeological objects have been generally altered due to diagenetic processes during burial strongly depending on the respective environmental conditions. Nevertheless, the magnesium to calcium ratio can serve as identification criteria for well preserved ivories as well as in the case when archaeological artifacts coming from the same archaeological layers are available. In this way variation of influencing factors linked to diagenetic processes can be minimized.

In a second approach the micro-morphology of the various bone materials was studied by means of microtomography using synchrotron (SR microCT) and a laboratory source.

Previous investigations by means of SR microCT analysis on modern ivory, bone and antler have shown that bone and antler clearly can be differentiated from ivory. The microstructure of compact bone and antler is characterized by histological units called osteons $(100-200 \mu \mathrm{m}$ in diameter). Osteons are composed of circularly-distributed layers (lamellae) of collagen fibril bundles (layer thickness $-2-3 \mu \mathrm{m}$ ) around the Haversian channels (containing blood vessels) (Currey, 2002; Wagermaier et al., 2006). The micro-morphological variations between bone and antler are quite subtle and, therefore, the differentiation between them, especially for altered samples, is not obvious. By contrast, the micro-structure of the dentine part of ivory is characterized by dentine tubules (ca. $2 \mu \mathrm{m}$ in diameter) embedded in a matrix forming micro-laminae (Locke, 2008). Haversian systems are absent. These micromorphological characteristics have also been identified for Palaeolithic samples coming from the same archaeological layer (Reiche et al., 2011). 


\section{Chemical and micro-morphological INVESTIGATION OF THE BEADS AND OF ARCHAEOLOGICAL REFERENCE MATERIAL FROM LeVEl 2 OF THE ABri PATAUd}

\section{Material and Methods}

A total of 12 rectangular beads (AU_AP_19-30) coming from level 2 of the abri Pataud were analyzed by non-destructive microPIXE analysis in order to determine the raw material used for their manufacture (fig. 5). Several visually determined bone (AB_AP_8, 9), antler (AA_AP_6, 7) and ivory fragments (AI_AP_1(I,II,III), 2, 3, 4, 5), also excavated at Pataud level 2, served as archaeological reference materials coming from the same archaeological context (Table 2). Additionally, six of these Pataud beads and two recently excavated ones without varnish at their surface from the same archaeological layer (AU_AP_31 and _34) could be scanned using microCT to study non-destructively their micro-morphology. It is aimed to find micro-morphological differences between ivory, bone and antler, which could serve as identification markers.

\section{Proton Induced X-ray emission analysis}

The analyses were conducted at the external micro-beam line at the $2 \mathrm{MV}$ tandem particle accelerator AGLAE at the LC2RMF, Paris (Calligaro et al., 2004). The system is equipped with two $\mathrm{X}$-ray detectors $(\mathrm{Si}(\mathrm{Li}))$. The objects were placed on an assessable sample stage in front of the accelerator. The analyses were carried out in air with helium purging. MicroPIXE/PIGE analyses provide the major, minor

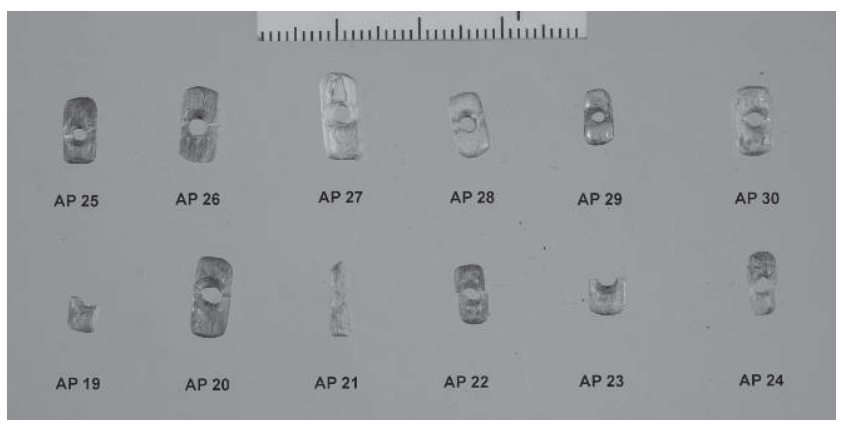

Figure 5: (See colour plate) Rectangular beads (AU_AP_19-30) from level 2 of abri Pataud chosen for the microPIXE analyses. Six of them were selected for the microCT scans.

Figure 5: (Voir planche couleur) Perles rectangulaires ( $A U_{-} A P_{-}$1930) du niveau 2 de l'abri Pataud choisies pour les analyses en microPIXE. Six d'entre elles ont été sélectionnées pour les analyses par microCT. and trace elemental composition with detection limits between 5 and $30 \mathrm{ppm}$ for elements heavier than $\mathrm{Ti}$ and between 100 and $300 \mathrm{ppm}$ for light elements ( $\mathrm{Na}$ to $\mathrm{Ti}$ ). MicroPIXE is a surface-sensitive method. At least three measurements were performed per sample. The analyzed area varied between 50 and $500 \mu \mathrm{m}$ depending on the sample size and morphology. The PIXE data were evaluated with the software GUPIX based on fundamental parameter method (Maxwell et al., 1988).

\section{Synchrotron and laboratory micro-Computed Tomography}

MicroCT measurements were carried out by means of the laboratory microCT device at BAM and at BAMline at the synchrotron source BESSY II, Helmholtz-Zentrum Berlin für Materialien und Energien (HZB). The BAM microCT device is equipped with a $225 \mathrm{kV}$ microfocal tube (Comet Business Unit Feinfocus) with reflection target and a focal spot of about $8 \mu \mathrm{m}$ at $8 \mathrm{~W}$ and a flat panel detector (PerkinElmer) with a structured CsI scintillator and 2048x2048 pixels of $0.2 \mathrm{~mm}$ size. The measurements described here were performed using an acceleration voltage of $60 \mathrm{kV}$ and a pre-filter of $1 \mathrm{~mm} \mathrm{Al}$. The synchrotron microCT measurements were performed using monochromatic radiation varying between 13.5 and $15 \mathrm{keV}$. For one CT scan images at 1500 to 3000 angles per $180^{\circ}$ were measured with an individual exposure time ranging from 2 to $5 \mathrm{~s}$ per measuring point. A mean CT scan of one sample lasted for about $3 \mathrm{~h}$. Samples were fixed in a Kapton ${ }^{\circ}$ tube with a diameter of 1,2 or $4 \mathrm{~mm}$ adapted to the size of the bone fragment or object under investigation. The detailed set-up is explained in details in the following references (Rack et al., 2008; Riesemeier et al., 2009; Reiche et al. 2011). The voxel data were reconstructed for both laboratory and SR microCT with a filtered-backprojection algorithm and visualized using the software VGStudio Max 2.1 (VolumeGraphics $\mathrm{GmbH}$, Heidelberg/Germany). The reconstructed volumes have a voxel size between $0.4 \mu \mathrm{m}$ (gained only with SR) and $3.6 \mu \mathrm{m}$ depending on the object's size. Virtual sections (2D images) of the samples are generally represented.

\section{Results}

\section{Raw material identification by means of chemical markers}

After a first study using the C2RMF data base on archaeological and recent bone material (Müller et al., 2009), it was decided to use in this study archaeological reference mate- 


\begin{tabular}{|c|c|c|c|c|c|c|c|c|c|c|c|}
\hline $\begin{array}{l}\text { C2RMF } \\
\text { sample } N^{\circ}\end{array}$ & $\begin{array}{l}\text { Pataud piece } \\
\mathrm{N}^{\circ}\end{array}$ & Excavation & Type of piece & Condition & $\begin{array}{c}\text { Lenghth } \\
(\mathrm{mm})\end{array}$ & $\begin{array}{l}\text { Width } \\
(\mathrm{mm})\end{array}$ & $\begin{array}{l}\text { Thickness } \\
(\mathrm{mm})\end{array}$ & $\begin{array}{l}\text { Pigment } \\
\text { présence }\end{array}$ & $\begin{array}{l}\text { Varnished } \\
\text { piece }\end{array}$ & $\begin{array}{c}\text { Micro- } \\
\text { PIXE/PIGE } \\
\text { analyse }\end{array}$ & $\begin{array}{l}\text { Micro CT } \\
\text { analyse }\end{array}$ \\
\hline AU_AP_19 & $\mathrm{AP} / 63-2-2117$ & Movius, 1963 & Rectangular bead & $\begin{array}{l}\text { half bead, broken at the } \\
\text { perforation place }\end{array}$ & - & - & - & yes & yes & yes & no \\
\hline AU_AP_20 & $\mathrm{AP} / 63-2-2117$ & Movius, 1963 & Rectangular bead & $\begin{array}{l}\text { broken at the } \\
\text { perforation place } \\
\text { ( } 2 \text { fragments) }\end{array}$ & 10,0 & 4,5 & - & yes & yes & yes & no \\
\hline AU_AP_21 & $\mathrm{AP} / 63-2-2117$ & Movius, 1963 & Rectangular bead & $\begin{array}{l}\text { half bead, broken in the } \\
\text { lengthways }\end{array}$ & 9,0 & - & - & yes & yes & yes & no \\
\hline AU_AP_22 & $\mathrm{AP} / 63-2-2117$ & Movius, 1963 & Rectangular bead & $\begin{array}{l}\text { broken at the } \\
\text { perforation place } \\
\text { ( } 2 \text { fragments) }\end{array}$ & - & 4,0 & - & yes & yes & yes & no \\
\hline AU_AP_23 & $\mathrm{AP} / 63-2-2117$ & Movius, 1963 & Rectangular bead & $\begin{array}{l}\text { broken at the } \\
\text { perforation place } \\
\text { ( } 2 \text { fragments) }\end{array}$ & - & 4,5 & - & yes & yes & yes & laboratory CT \\
\hline AU_AP_24 & $\mathrm{AP} / 63-2-2117$ & Movius, 1963 & Rectangular bead & $\begin{array}{l}\text { broken at the } \\
\text { perforation place and } \\
\text { in the thicknessways } \\
\text { ( } 3 \text { fragments) }\end{array}$ & - & 4,0 & - & yes & yes & yes & synchrotron \\
\hline AU_AP_25 & $\mathrm{AP} / 63-2-2117$ & Movius, 1963 & Rectangular bead & $\begin{array}{l}\text { broken at the } \\
\text { perforation place } \\
\text { ( } 2 \text { fragments) }\end{array}$ & 8,0 & 4,0 & - & yes & yes & yes & no \\
\hline AU_AP_26 & $\mathrm{AP} / 63-2-2117$ & Movius, 1963 & Rectangular bead & $\begin{array}{l}\text { broken at the } \\
\text { perforation place } \\
\text { ( } 2 \text { fragments) }\end{array}$ & 9,0 & 5,0 & - & yes & yes & yes & no \\
\hline AU_AP_27 & $\mathrm{AP} / 63-2-1710$ & Movius, 1963 & Rectangular bead & $\begin{array}{l}\text { complete except a } \\
\text { small fragment in the } \\
\text { thickness }\end{array}$ & 10,5 & 5,0 & 3,5 & yes & yes & yes & laboratory CT \\
\hline AU_AP_28 & AP/63-2-1827 & Movius, 1963 & Rectangular bead & complete & 8,0 & 4,0 & 2,5 & yes & yes & yes & laboratory CT \\
\hline AU_AP_29 & $\mathrm{AP} / 63-2-2101$ & Movius, 1963 & Rectangular bead & $\begin{array}{l}\text { broken at the } \\
\text { perforation place } \\
\text { ( } 2 \text { fragments) }\end{array}$ & 7,0 & 4,0 & 1,5 & yes & yes & yes & synchrotron \\
\hline AU_AP_30 & $\mathrm{AP} / 63-2-2084$ & Movius, 1963 & Rectangular bead & complete & 8,5 & 4,5 & 3,0 & yes & yes & yes & $\begin{array}{l}\text { synchrotron + } \\
\text { laboratory CT }\end{array}$ \\
\hline AU_AP_31 & $\begin{array}{l}\text { AP/08-NET- } \\
86-T 683\end{array}$ & $\begin{array}{l}\text { Nespoulet, } \\
\text { Chiotti, } 2008\end{array}$ & Rectangular bead & $\begin{array}{l}\text { broken at the } \\
\text { perforation place } \\
\text { ( } 2 \text { fragments) }\end{array}$ & - & - & - & yes & no & no & synchrotron \\
\hline AU_AP_32 & $\begin{array}{l}\text { AP/08-NET- } \\
86-T 682\end{array}$ & $\begin{array}{l}\text { Nespoulet, } \\
\text { Chiotti, } 2008\end{array}$ & Rectangular bead & $\begin{array}{l}\text { broken at the } \\
\text { perforation place } \\
\text { ( } 2 \text { fragments) }\end{array}$ & - & - & - & yes & no & no & no \\
\hline AU_AP_33 & $\begin{array}{l}\text { AP/08-NET- } \\
86-T 680\end{array}$ & $\begin{array}{l}\text { Nespoulet, } \\
\text { Chiotti, } 2008\end{array}$ & Rectangular bead & complete & 7,5 & 4,0 & 2,0 & yes & no & no & no \\
\hline AU_AP_34 & $\begin{array}{l}\text { AP/08-W75C- } \\
\text { 92-T816 }\end{array}$ & $\begin{array}{l}\text { Nespoulet, } \\
\text { Chiotti, } 2008\end{array}$ & Rectangular bead & complete & 6,5 & 3,5 & 1,5 & yes & no & no & synchrotron \\
\hline AI_AP_1 & $\mathrm{AP} / 58-2-309$ & Movius, 1958 & $\begin{array}{l}\text { Ivory fragments } \\
\text { from a Mammoth } \\
\text { Tusk segment }\end{array}$ & 3 fragments & - & - & - & no & no & yes & laboratory CT \\
\hline AI_AP_2 & $\begin{array}{l}\mathrm{AP} / 58-2- \\
37795\end{array}$ & Movius, 1958 & Ivory fragment & 1 fragment & 75,0 & 56,0 & 11,5 & no & no & yes & no \\
\hline AI_AP_3 & $\begin{array}{l}\mathrm{AP} / 58-2- \\
37799\end{array}$ & Movius, 1958 & Ivory fragment & 1 fragment & 33,0 & 18,5 & 6,5 & no & no & yes & no \\
\hline AI_AP_4 & $\begin{array}{l}\mathrm{AP} / 89-2- \\
37798\end{array}$ & 1989 & Ivory fragment & 1 fragment & 20,0 & 12,5 & 3,0 & no & no & yes & no \\
\hline AI_AP_5 & $\begin{array}{l}\text { AP/58-2- } \\
37793\end{array}$ & Movius, 1958 & Ivory fragment & 1 fragment & 14,0 & 11,0 & 6,0 & no & no & yes & no \\
\hline AA_AP_6 & $\begin{array}{l}\text { AP/07- } \\
\text { W76A-129 }\end{array}$ & $\begin{array}{l}\text { Nespoulet, } \\
\text { Chiotti, } 2007\end{array}$ & Reindeer antler & 2 fragments & 53,7 & 25,6 & 13,0 & no & no & yes & no \\
\hline AA_AP_7 & $\begin{array}{l}\text { AP/07- } \\
\text { W77D-20 }\end{array}$ & \begin{tabular}{|l|} 
Nespoulet, \\
Chiotti, 2007
\end{tabular} & Reindeer antler & 1 fragment & 28,4 & 10,0 & 7,9 & no & no & yes & laboratory CT \\
\hline AB_AP_8 & $\begin{array}{l}\text { AP/07- } \\
\text { V77D-146 }\end{array}$ & $\begin{array}{l}\text { Nespoulet, } \\
\text { Chiotti, } 2007\end{array}$ & Bone & 1 fragment & 72,8 & 27,6 & 26,6 & no & no & yes & laboratory CT \\
\hline AB_AP_9 & $\begin{array}{l}\text { AP/07- } \\
\text { V76B-132 }\end{array}$ & \begin{tabular}{|l|} 
Nespoulet, \\
Chiotti, 2007
\end{tabular} & Bone & 11 fragments & 77,9 & 53,7 & 13,6 & no & no & yes & no \\
\hline
\end{tabular}

Table 2: Description of the investigated samples from Final Gravettian level 2 of the abri Pataud analysed by microPIXE and/or microCT. Tableeau 2: Description des échantillons du niveau 2 (Gravettien Final) de l'abri Pataud, analysés par microPIXE et/ou microCT. 
rials for bone, antler and ivory coming from the same level 2 of the abri Pataud as the beads. In figure 6 the magnesium to calcium ratios for these bone materials are displayed. This graph shows that ivory can be separated from bone and antler even for these Palaeolithic fragments as all, except of one, abri Pataud ivories tends to result in higher magnesium and/ or lower calcium values than bone and antler. A chemical differentiation between bone and antler is not possible. The magnesium to calcium ratios obtained for the beads from abri Pataud, which are dispersed largely, are also given in figure 6. Unfortunately, most of the beads lie between the two groups found for the abri Pataud reference materials and a definitive identification of the raw materials used is therefore not possible by means of the applied method. Two beads display relatively high calcium and magnesium values that can be attributed to sediment residues on the beads surface. The magnesium to calcium ratio of bead AU_AP_28 is comparable to that of bone or antler.

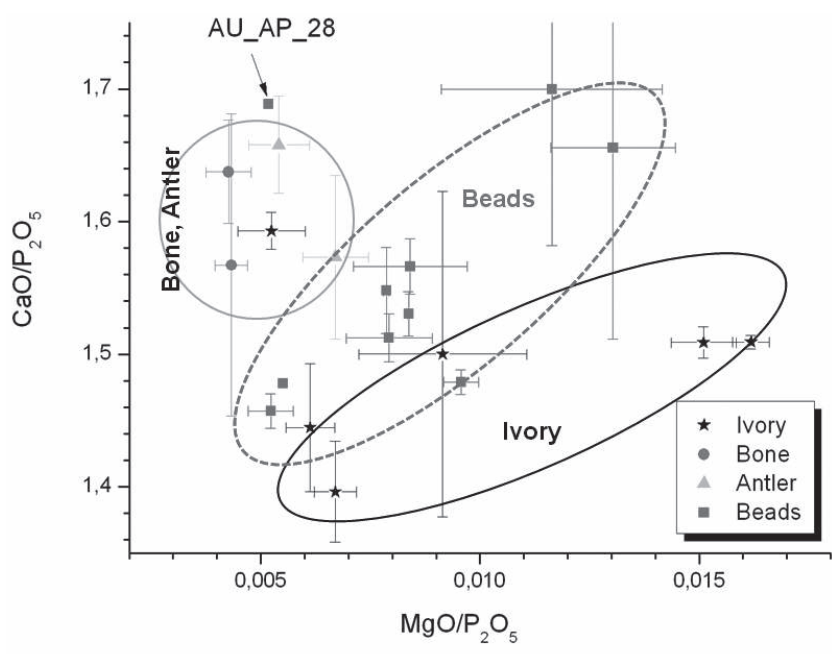

Figure 6: Magnesium to calcium ratios for the analyzed beads and reference materials from abri Pataud (Dordogne, France). The magnesium and calcium values were normalized to the main component of bone apatite, the phosphate, in order to minimize quantification errors by disregarding the organic fraction (Müller \& Reiche, 2011). (AP = Abri Pataud)

Figure 6 : Rapport magnésium sur calcium pour les perles analysées et les matériaux de référence de l'abri Pataud (Dordogne, France). Les valeurs de magnésium et de calcium sont normalisées par rapport au composant principal de l'apatite de l'os, le phosphate, afin de minimiser les erreurs de quantification due à l'omission de la fraction organique (Müller \& Reiche, 2011). (AP = Abri Pataud)

\section{Raw material identification based on micro-morphological characteristics by microCT analyses}

Previous investigations by means of SR microCT showed that bone and antler clearly can be differentiated from ivory by the presence of the characteristic Haversian systems,

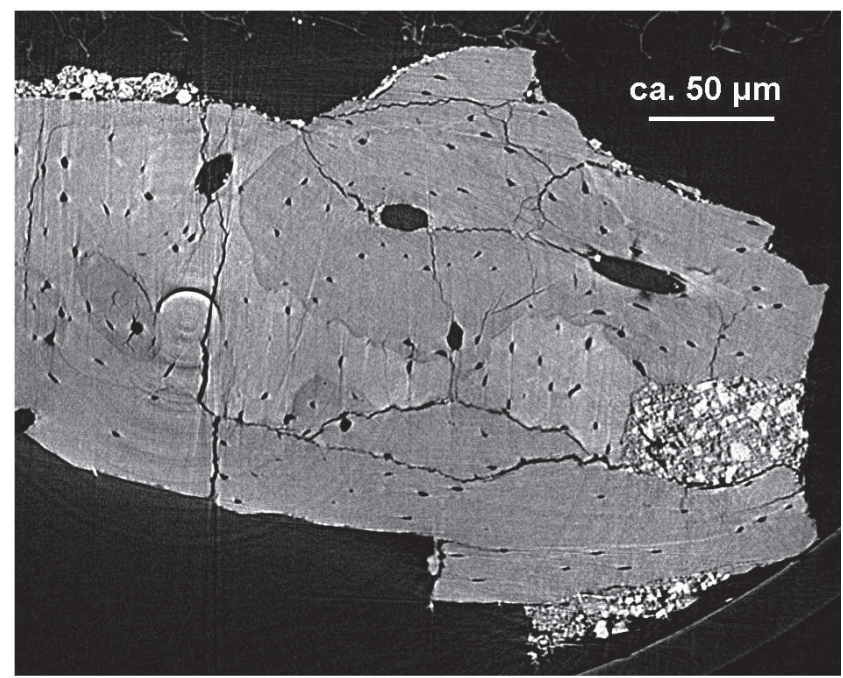

Figure 7: SR microCT virtual cross section of a reindeer bone from level 2 at abri Pataud (AB_AP_8).

Figure 7: Coupe transversale virtuelle obtenue par SR microCT d'un os de renne du niveau 2 de l'abri Pataud ( $\left.A B \_A P \_8\right)$.

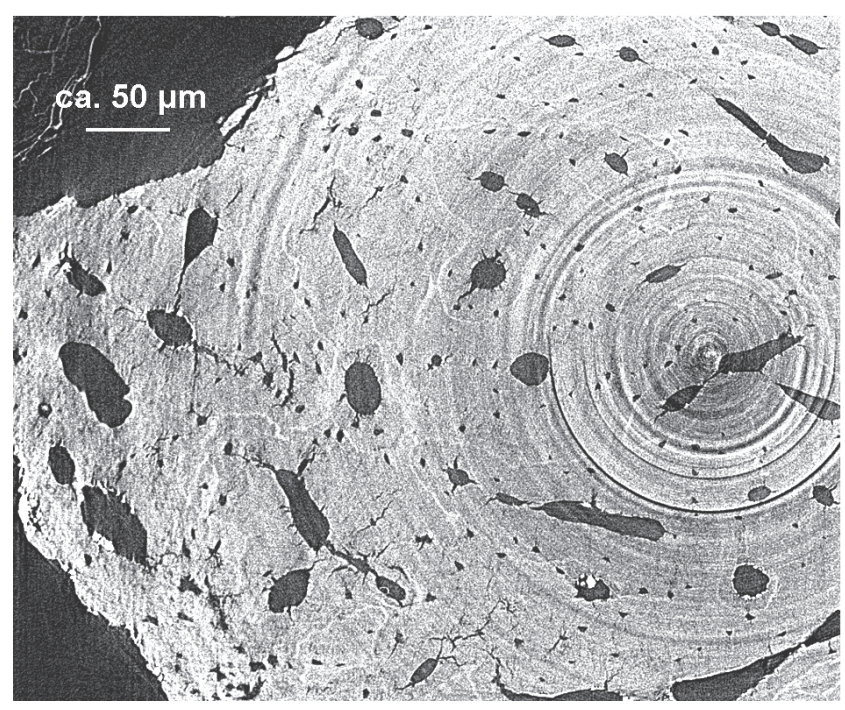

Figure 8: SR microCT virtual cross section of a fragment of reindeer antler (AA_AP_7) found at level 2 of the abri Pataud.

Figure 8: Coupe transversale virtuelle obtenue par SR microCT d'un fragment de bois de renne ( $\left.A A_{-} A P \_7\right)$ découvert dans le niveau 2 de l'abri Pataud. 


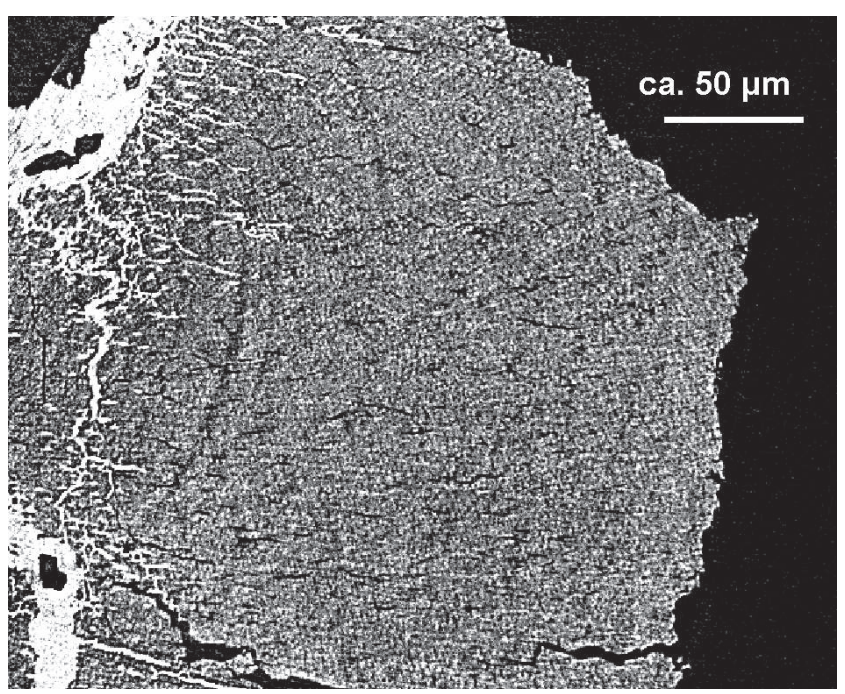

Figure 9: SR microCT virtual cross section of a mammoth tusk fragment (AI_AP_1) from level 2 of abri Pataud.

Figure 9: Coupe transversale virtuelle obtenue par SR microCT d'un fragment de défense de mammouth ( $\left.A I \_A P \_1\right)$ du niveau 2 de l'abri Pataud.

which are absent in ivory. By contrast, ivory is characterized by tubular pores of 1 to $2 \mu \mathrm{m}$ in diameter (Reiche $e t$ al., 2011).

These characteristic features could also be observed for the archaeological reference materials coming from level 2 of abri Pataud, as can be seen in the figures 7, 8 and 9 .

For the bone (AB_AP_8) and antler (AA_AP_7) fragments the characteristic bone features appear quite well preserved (fig. $7 \&$ 8). Osteon structures with Haversian channels (diameters between 20 and $50 \mu \mathrm{m}$ ) can clearly be recognized. Next to the surface of the bone fragment, very likely inclusions of secondary minerals or sediment remains, maybe iron-oxide rich clay, can be identified. The mammoth ivory fragment from abri Pataud (AI_AP_1) exhibits characteristic ivory morphological features, visible in the form of tubular pores with a diameter of about $2 \mu \mathrm{m}$, even if they appear slightly diagenetically altered (fig. 9) (Reiche et al., 2011). Haversian systems are absent. As a result of diagenetic changes this ivory fragment displays small to larger fissures, which are partly filled with secondary minerals (maybe iron-rich clay).

A total of five Pataud beads could be CT scanned at the synchrotron facility (AU_AP_24, 29, 30, 31 and 34). Additionally, because of their bigger size and for comparison reasons, four beads have been scanned with the help of the BAM laboratory CT device (AU_AP_23, 27, 28 and 30).

The $2 \mathrm{D}$ images in figures 10,11 and 12 correspond to virtual cross sections of the beads AU_AP_27, 28, 29 and

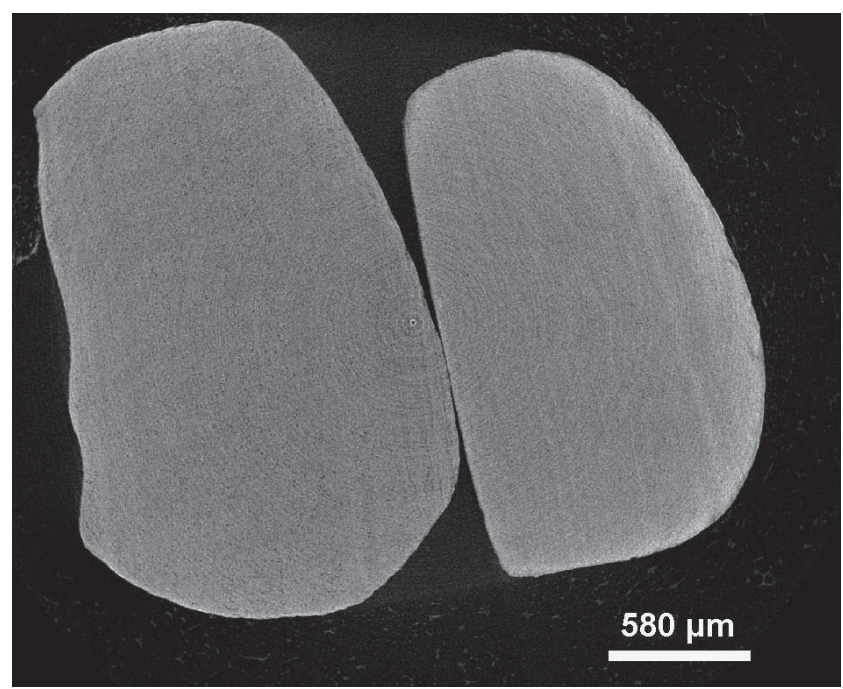

Figure 10: Virtual cross section of the beads AU_AP_27 and _28 scanned by means of the laboratory CT device, voxel size $3.6 \mu \mathrm{m}$. Figure 10: Coupe transversale virtuelle des perles $A U \_A P \_27$ et_28 obtenues avec un appareil de micro CT de laboratoire, taille des voxels 3,6 $\mathrm{mm}$.

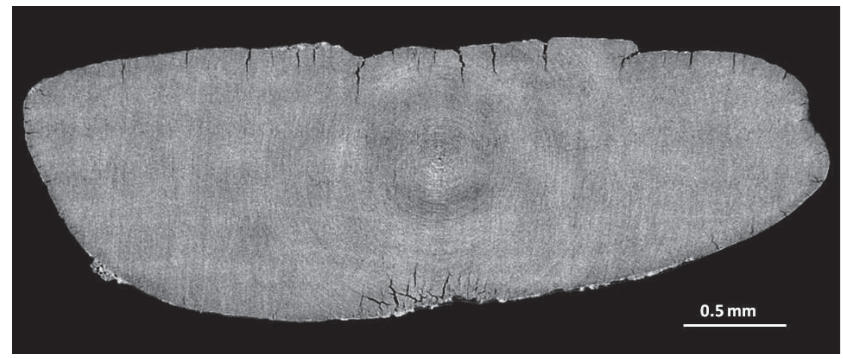

Figure 11: SR microCT virtual cross section of bead AU_AP_29, voxel size $2.18 \mu \mathrm{m}$. Many fissures at the outer part of the bead can be recognized.

Figure 11: Coupe transversale virtuelle obtenue par SR microCT de la perle AU_AP_29, taille des voxels 2,18 $\mathrm{mm}$. Des fissures sont visibles sur la partie externe de la perle.

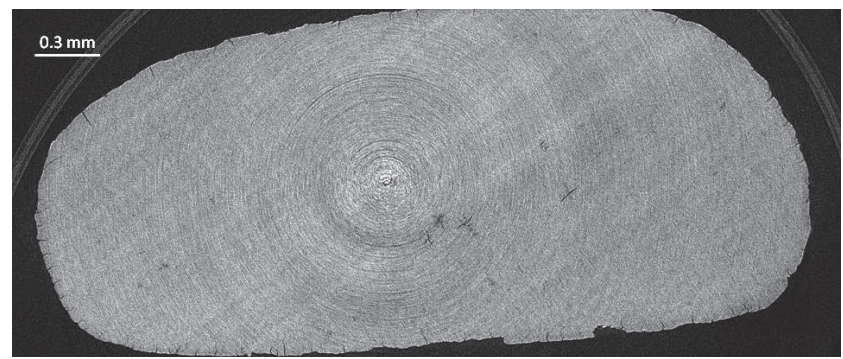

Figure 12: Virtual cross section through the bead AU_AP_34 gained by using SR microCT, voxel size $1.08 \mu \mathrm{m}$.

Figure 12: Coupe transversale virtuelle de la perle $A U \_A P \_34$ obtenue par SR microCT, taille des voxels 1,08 $\mathrm{mm}$. 
34. These images display the microstructure of ivory characterized by the presence of small $\mu \mathrm{m}$-sized tubules and the absence of osteon structures with Haversian channels (fig. 10, 11). The $\mu \mathrm{m}$-sized tubules can be recognized in the close-up view of bead AU_AP_34 (fig. 12) when SR microCT could be applied. Figure 11 indicates the formation of cracks and fissures in bead AU_AP_29, basically in the outer region, as further alteration features of the ivory microstructure. Similar morphological features have been determined for the beads AU_AP_23, 24 and 31. Consequently, it can be assumed that these beads were made of ivory, and according to the archaeological context, mammoth ivory.

In figure 13 a virtual cross section for one bead $\left(\mathrm{AU}_{-}\right.$ AP_30) is shown that clearly differs from the other beads analyzed here. The micro-morphology displays features like small Haversian systems with channels of 20 to $40 \mu \mathrm{m}$ in diameter. Therefore, for the manufacture of this bead the use of ivory is quite unlikely. Its micro-morphology corresponds more probably to the compact outer parts of antler because of the very regular distribution of mainly primary osteons

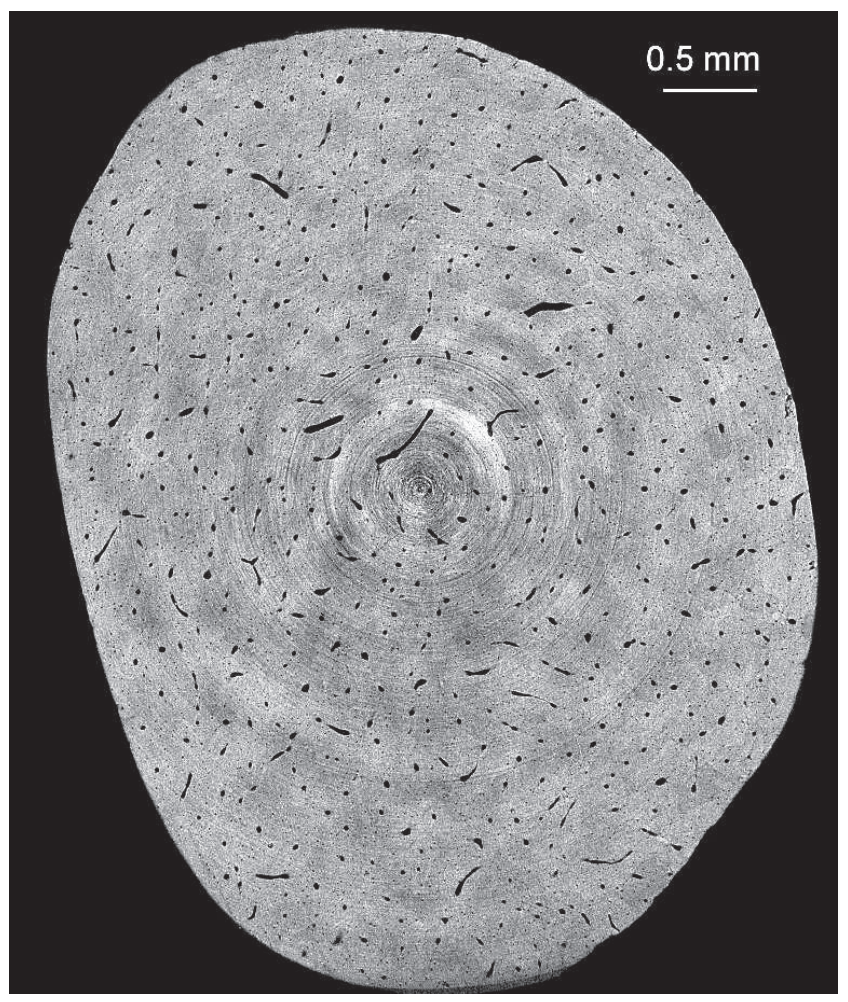

Figure 13: Virtual cross section of the bead AU_AP_30 (lateral dimension: $4.5 \times 3.5 \mathrm{~mm}^{2}$ ).

Figure 13: Coupe transversale virtuelle de la perle $A U \_A P \_30$ (dimension latérale: 4,5 ×3,5 $\mathrm{mm}^{2}$ ). in a bone-like matrix. The size of the osteons is also very similar and they seem less mineralized than the surrounding material. The latter features are also characteristic of antler (Krauß et al., 2011).

\section{Discussion \& Conclusion}

The 85 Final Gravettian rectangular beads from Pataud Level 2 are considered as characteristic of this culture. Nevertheless, a closer morphological study showed that these beads are not so standardized. There are small variations in size and two beads differ in section (biconvex instead of flat-convex like all other beads). We could argue that some variation in shape could be due to the kind of adornment (necklace, bracelet...) in which beads are included and also the position within this body ornamentation. Another hypothesis was that a difference in shape means the use of different raw materials.

Within this study two analytical approaches based on different material characteristics, the chemical composition on one hand and the micro-morphology on the other hand, were applied on a selection of rectangular beads from abri Pataud in order to identify the raw material used. In general, ivory can be chemically distinguished from bone and antler by its enhanced magnesium to calcium ratio. However, the chemical approach was limited because of alterations of chemical composition caused by diagenetic processes during burial. A further difficulty of the chemical analyses was the varnish layer applied on the bead's surface in the course of ancient conservation treatments. The information depth of the PIXE method is only a few microns for light elements like magnesium. Therefore, the varnish layer may have a non-negligible influence on the detection of magnesium in the beads resulting in lower magnesium to calcium ratios, thus hampering identification of the material.

By micro-morphological investigations applying laboratory and synchrotron microCT devices ivory could be identified as the raw material used for the manufacture of all but one studied beads from level 2 of the abri Pataud. This is a particularly striking result in view of the fact that mammoth ivory is relatively rare in Pataud level 2. In this level, bones and fragments of reindeer antler are very abundant whereas mammoth remains were identified only for 18 pieces (not counting the rectangular beads): one femur fragment, one worked tusk fragment, nine beads and pendants and seven raw ivory fragments. The small number of mammoth remains, the high proportion of transformation and the type of artifacts manufactured allow us to allocate a particular status to this raw material. 
Therefore, we are able to demonstrate the exceptional status of the beads, because of their archaeological context, a Final Gravettian mortuary deposit, and also through the particular - and rare - raw material chosen to manufacture them.

For only one bead, AU_AP_30, a micro-morphology more likely corresponding to antler was detected. Moreover, this bead is also one that we noticed before as having a different shape (biconvex section) with respect to most of the others (flat-convex section). But we do not have enough objects and enough evidence about the chaîne opératoire and the way beads were arranged to know if this is a coincidence or not. We cannot exclude that in some cases (lack of the required raw material?) people used antler in order to mimic ivory.

We also pointed out that all rectangular beads associated with human remains from Pataud level 2 were worn. It leads us to conclude that these rectangular beads were not manufactured especially for the mortuary deposition and then could correspond to a part of the body ornamentation during life time.

If we consider all the archaeological information available for the level 2 of the abri Pataud, i.e.:

- rectangular beads are a part of extra-ordinary objects associated with human remains in a mortuary context (Chiotti et al., 2009);

- this specific kind of beads was not discovered within the living zone;

- mammoth ivory could be considered as a rare material within this site; except one fragment of bone, mammoth is only represented in this level by ivory, which was used to produce body ornaments;

- the manufacturing of these relatively standardized rectangular beads should require a long time and a major technical investment,

- it is likely that prehistoric people could have made a choice of a particular material type for body ornaments. This choice could be linked not only with the mortuary context, but also with age, gender and social status of people who were buried (Vanhaeren \& d'Errico, 2005). However, the comparison with the other French Final Gravettian sites is relatively limited: only two other sites, Les Peyrugues and Le Blot, provided similar rectangular beads and at Les Peyrugues these beads are supposed to be made of reindeer antler (Allard et al., 1997).

At the abri Pataud, the use of mammoth ivory is not only restricted to the rectangular beads and the mortuary context, as some other ivory beads and pendants were discovered outside this area of human remains deposition. Therefore, in the discussion about the choice of mammoth ivory to produce rectangular beads, and other body ornaments from level 2, we must also strongly consider the influence of the intrinsic qualities of this raw material (e.g. whiteness, translucence, smoothness; Christensen, 2004).

Finally, we could wonder if beyond the objects (body ornaments) and their raw material (ivory), the animal (mammoth) could have held a particular status for the Final Gravettian populations of this region. This question could also be raised with regard to the mobile art object discovered in the fourth French Final Gravettien site, Laugerie-Haute Est (Dordogne), by D. Peyrony: a bâton percé made of reindeer antler, on which two mammoths, forehead against forehead, were engraved (Peyrony, 1935; Peyrony \& Peyrony, 1938; Dubourg, 1997).

In order to go further in our researches about animal exploitation and social systems within the Final Gravettian hunter-gatherer societies, we need now to carry out studies about the origins of mammoth ivory used to manufacture body ornaments from Pataud level 2 and to evaluate the availability of this raw material for Final Gravettian craftsmen. It would also be interesting to study the beads from other contemporaneous sites using the same analytical approach.

\section{Acknowledgements}

We acknowledge the Helmholtz-Zentrum Berlin - Electron storage ring BESSY II for provision of synchrotron radiation at BAMline during two experiments with the contract numbers: 2008.1.70139 and 2010.2.100069. The research leading to these results has received funding from the European Community's Seventh Framework Programme (FP7/20072013) under grant agreement $n .{ }^{\circ} 226716$. The authors thank several collaborators of the BAM: Karsten Ehrig, Bernd Müller, Jürgen Goebbels and Ralf Britzke for their help during microCT measurements and the AGLAE team at C2RMF for its support during PIXE analyses. Stefanie Krauß (Department of Biomaterials, Max Planck Institute of Colloids and Interfaces, Potsdam-Golm) is thanked for the help during the antler identification. The project was supported by the ANR projects ANR07-JCJC-0149 (ArBoCo 2007-10) and BLAN07-2_185221 (MADAPCA 2007-11). 


\section{References}

Allard, M., Drieux, M., Jarry, M., Pomies, M.-P., Rodière, J., 1997 - Perles en bois de renne du niveau 18 des Peyrugues, à Orniac (Lot). Hypothèse sur l'origine du Protomagdalénien. Paléo, 9: 355-369.

Barone, R.,1986 - Anatomie comparée des Mammiferes domestiques. Tome 1 : Ostéologie. Vigot Frères, Paris, $3^{\mathrm{e}}$ édition, $761 \mathrm{p}$.

Bricker, H. M., 1995 - Le Paléolithique supérieur de l'abri Pataud (Dordogne) : les fouilles de H. L. Movius Jr. Editions de la maison des sciences de l'homme, Paris, Documents d'archéologie française, 50 .

Calligaro, T., Dran, J. C., Salomon, J., Walter, P., 2004 Review of accelerator gadgets for art and archaeology. Nuclear Instruments and Methods in Physics Research Section B, 226: 29-37.

Chauvière, F.-X., Fontana, L., 2005 - Modalités d'exploitation des rennes dans le Protomagdalénien du Blot (HauteLoire, France) : entre subsistance, technique et symbolique. In $\mathrm{V}$. Dujardin, Industries osseuses et parures du Solutréen au Magdalénien en Europe, actes de la table ronde sur le Paléolithique supérieur récent, Angoulême (28-30 mars 2003). Société préhistorique française, Paris, Mémoires de la SPF, XXXIX, p. 137-147.

Chiotti, L., Nespoulet, R., Henry-Gambier, D., Morala, A., Vercoutère, C., with the collaboration of Agsous, S., Lenoble, A., Marquer, L., Grimaud-Hervé, D., 2009 - Statut des objets " extra-ordinaires " du Gravettien final de l'abri Pataud (Les Eyzies, Dordogne) : objets abandonnés dans l'habitat ou dépôt intentionnel ? In S.Bonnardin, C. Hamon, M.Lauwers and B.Quilliec (dir.). Du matériel au spirituel-Réalités archéologiques et historiques des "dépôts" de la Préhistoire à nos jours, actes des XXIX Rencontres internationales d'archéologie et d'histoire d'Antibes. Editions APDCA, Antibes, 29-46.

Christensen, M., 1999 - Technologie de l'ivoire au Paléolithique supérieur - Caractérisation physico-chimique du matériau et analyse fonctionnelle des outils de transformation. Archaeopress, Oxford, BAR International Series, 751.

Christensen, M., 2004 - Fiche caractères morphologiques, histologiques et mécaniques des matières dures d'origine animale. In : Ramseyer D. (dir.), Fiches de la Commission de nomenclature sur l'industrie de l'os préhistorique, Cahier XI : Matières et Techniques, éditions de la Société préhistorique française, Paris, 17-27.

Clay, R., 1968 - The Proto-Magdalenian Culture. Thèse de Doctorat, Southern Illinois University, Etats-Unis, 680 p.

Currey, J. D., 2002 - Bones: Structure and mechanics. Princeton University Press, Princeton, N.J.
Dubourg, C., 1997 - Les expressions du naturalisme dans les arts graphiques du Paléolithique supérieur. Une vision du monde des chasseurs préhistoriques. Thèse de Doctorat, Bordeaux 1, France.

EdWARDS, H. G. M., FARWELl, D. W., 1995 - Ivory and simulated ivory artefacts: Fourier transform Raman diagnostic study. Spectrochimica Acta Part A, 51: 2073-2081.

Henry-Gambier, D., 2008 - Comportement des populations d'Europe au Gravettien : pratiques funéraires et interprétations. Paléo, 20 : 399-438.

Henry-Gambier, D, Villotte, S., Bruzek, J., Beauval, C., in prep. - Les vestiges humains : données biologiques et contextualisation. In R. Nespoulet, L. Chiotti, D. Henry-Gambier (ed.), Le Gravettien final de l'abri Pataud (Dordogne, France). Résultats des fouilles et des études 2005-2009, Archaeopress, Oxford, British Archaeological report International Series.

Krauss, S., Wagermaier, W., Estevez, J.E., Currey, J. D., Fratzl, P., 2011 - Tubular frameworks guiding orderly bone formation in the antler of the red deer (Cervus elaphus). Journal of Structural Biology, doi: 10.1016:j.jsb.2011.06.005.

LOCKE, M., 2008 - Structure of Ivory. Journal of Morphology, 269: 423-450.

Maxwell, J. A., Campbell, J. L., Teesdale, W. J., 1988 - The Guelph PIXE Software. A description of the code package. Nuclear Instruments and Methods in Physics Research B, 43: 218-230.

Movius, H. L. Jr., 1977 - Excavation of the abri Pataud, Les Eyzies (Dordogne): Stratigraphy. Peabody Museum, Harvard University, Cambridge, Massachusetts, American School of Prehistoric Research, bull. 31.

Müller, K., Chadefaux, C., Rodière, J., Chiotti, L., Nespoulet, R., Vercoutère, C., Menu, M., Reiche, I., 2009 - Knochen, Elfenbein oder Geweih? Die paläolithischen Perlen aus dem Abri Pataud ( 22000 BP, Dordogne, Frankreich). In A. Hauptmann and H. Stege (Dir.), Archäometrie und Denkmalpflege 2009, Jahrestagung in der Pinakothek der Moderne München, Metalla, Sonderheft 2, Bochum 2009, 78-80.

MÜlleR, K. \& ReICHE, I., 2011 - Differentiation of archaeological ivory and bone materials by micro-PIXE/PIGE with emphasis on two Upper Palaeolithic key sites: Abri Pataud and Isturitz, France. Journal of Archaeological Science, doi: 10.1016/j. jas.2011.06.029.

Nespoulet, R., Chiotti, L., Agsous, S., Guillermin, P., Grimaud-Hervé, D., Henry-Gambier, D., Lenoble, A., Marquer, L., Morala, A., Patou-Mathis, M., Pottier, C., Vannoorenberghe, A., Vercoutère, C., Vérez, M., 2008 - L'occupation humaine de l'abri Pataud il y a 22000 ans : problématique et résultats préliminaires des fouilles du niveau 2. In J. Jaubert, J.-G. Bordes and I. Ortega (dir.), Les sociétés paléolithique dans un Grand Sud-Ouest de la France : nouveaux 
gisements, nouveaux résultats, nouvelles méthodes. Actes des Journées de la Société préhistorique française, Mémoire de la Société Préhistorique Française, XLVII, 325-334.

Peyrony D., 1935 - Le Protomagdalénien de Laugerie-Haute, Commune des Eyzies-de-Tayac (Dordogne). Comptes Rendus de l'Association Française pour l'Avancement des Sciences, Nantes, 381-383.

Peyrony, D., Peyrony, E, 1938 - Laugerie-Haute, près des Eyzies (Dordogne). Editions Masson, Paris (Archives de l'Institut de Paléontologie Humaine, 19).

Poplin, F., 1995 - Délitage et débitage dans le travail de l'ivoire vrai sur des exemples du début du Paléolithique supérieur. In J. Hahn, M. Menu, Y. Taborin, Ph. Walter \& F. Widermann (eds.), Le travail et l'usage de l'ivoire au Paléolithique supérieur, Actes de la Table Ronde de Ravello, 29-31 mai 1992, Rome: Ist. Poligrafico e Zecca dello Stato, 17-27.

RaCK, A., Zabler, S., Müller, B.R., Riesemeier, H., WeidemanN, G., Lange, A., Goebbels, J., Hentschel, M., Görner, W., 2008 - High resolution synchrotron-based radiography and tomography using hard X-rays at the BAMline (BESSY II). Nuclear Instruments and Methods in Physics Research A, 586: 327-344.

Reiche, I., Müller, K., Staude, A., Goebbels, J., Riesemeier, H, 2011 - Synchrotron radiation and laboratory micro X-ray computed tomography -useful tools for the material identification of prehistoric objects made of ivory, bone or antler. Journal of Analytical Atomic Spectrometry, doi: 10.1039/ C0JA00246A.

Riesemeier, H., Rack, A., Zabler, S., Goebbels, J., Müller, B., R., BANHART, J. 2009 - The synchrotron-based imaging station for microradiography and-tomography at the BAMline (BESSY). Journal of Physics: Conference Series 186, 012047.
Vanhaeren, M., 2002 - Les fonctions de la parure au Paléolithique supérieur : de l'individu à l'unité culturelle. Thèse de Doctorat, Université Bordeaux I, France, 355 p.

Vanhaeren, M., D'Errico, F., 2003 - Childhood in the Epipaleolithic. What do personal ornaments associated to burials tell us? In: L. Larsson, H. Kindgren, K. Knutsson, D. Leoffler and A. Akerlund (Eds.), Mesolithic on the Move. Papers presented at the Sixth International Conference on the Mesolithic in Europe, Stockholm 2000, Oxbow Monographs, Oxford, 494-505.

Vanhaeren, M., D'Errico, F., 2005 - Grave goods from the SaintGermain-la-Rivière burial: Evidence for social inequality in the Upper Palaeolithic. Journal of Anthropological Archaeology, 24 (2005): 117-134.

Vercoutère, C., 2007 - De la viande à la pendeloque - Exemple de l'exploitation du Renne dans l'occupation gravettienne du niveau 2 de l'abri Pataud (Dordogne, France). In : S. Beyries, V. Vaté (dir.), Les civilisations du renne d'hier et d'aujourd'hui. Approches ethnohistoriques, archéologiques et anthropologiques, Actes des XXVII ${ }^{\mathrm{e}}$ Rencontres internationales d'archéologie et d'histoire d'Antibes, Juan-les-Pins, 19-21 octobre 2006. Editions APDCA, Antibes, 325-343.

Wagermaier, W., Gupta, H. S., Gourrier, A., Burghammer, M., Roschger, P., Fratzl, P., 2006 - Spiral twisting of fiber orientation inside bone lamellae. Biointerphases, 1 (1): 1-5.

WHITE, R., 1995 - Ivory personal ornaments of Aurignacian age: technological, social and symbolic perspectives. In J. Hahn, M. Menu, Y. Taborin, Ph. Walter \& F. Widermann (eds.), Le travail et l'usage de l'ivoire au Paléolithique supérieur, Actes de la Table Ronde de Ravello, 29-31 mai 1992, Rome : Ist. Poligrafico e Zecca dello Stato, 29-62. 